\title{
The antibacterial activity and toxin production control of bee venom in mouse MRSA pneumonia model
}

Ryong Kong ${ }^{1}$, Young-Seob Lee ${ }^{2}$, Dam-Hee Kang ${ }^{1}$, Shu Wang ${ }^{1}$, Qianqian Li', Dong-Yeul Kwon ${ }^{1}$ and

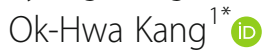

\begin{abstract}
Background: The current antimicrobial therapy is still important for the treatment of pneumonia due to MRSA infection, but there are some limitations, including the route of administration, side effect profile, and increased microbial resistance patterns. Therefore, we investigated whether BV, which shows a strong antimicrobial effect against MRSA, would be effective in a pneumonia model.

Methods: In vitro, we checked MIC, qRT-PCR, western blot, ELISA, LDH-assay. In vivo, we checked survival rate, gross pathological change, histopathology, lung bacterial clearance assay, and the expression of inflammatory related gene.

Results: The minimum inhibitory concentration of BV against MRSA is $15.6 \mu \mathrm{g} / \mathrm{ml}$ by broth dilution method. The production of toxins and related gene were reduced by BV in MRSA. The secretion of cytokines were decreased by treatment with BV in 264.7 RAW macrophages stimulated by MRSA Also, BV protected A549 from pathogenicity of MRSA. Bee venom reduced the number of bacteria in the lungs and alleviated the symptoms of MRSA-induced pneumonia in mouse.

Conclusion: BV inhibited the virulence of the bacterium and the number of bacterial cells present in lung tissue, thereby alleviating the symptoms of pneumonia in mice. This study suggested that BV may be a candidate substance for the treatment of pneumonia caused by MRSA infection.
\end{abstract}

Keywords: MRSA, Bee venom, Toxin, Pneumonia

\section{Background}

MRSA is a common cause of nosocomial pneumonia and healthcare-associated pneumonia [1]. The main cause of MRSA-induced pneumonia is toxin. The $\alpha$ hemolysin, a member of the $\beta$-barrel pore-forming toxin family, is the major virulence factor secreted by strains of $S$. aureus [2]. The $\alpha$-hemolysin is necessary for the pathogenesis of staphylococcal pneumonia. Bubeck Wardenburg et al. have reported that $S$. aureus mutants

\footnotetext{
*Correspondence: kangokhwa@daum.net

'Department of Oriental Pharmacy, College of Pharmacy and

Wonkwang-Oriental Medicines Research Institute, Wonkwang University, Iksan, Jeonbuk 54538, Republic of Korea

Full list of author information is available at the end of the article
}

lacking hla (the gene encoding $\alpha$-hemolysin) cannot cause neutrophil-mediated inflammatory lung injury in pneumonia model [3]. Similar to most staphylococcal extracellular proteins, the $\alpha$-toxin is not expressed constitutively but is tightly controlled by an array of extracellular and intracellular signals. At least three global regulatory loci the accessory gene regulator (agr), the staphylococcal accessory gene regulator $(\operatorname{sar} A)$, and the staphylococcal accessory protein effector (sae) appear to coordinately control the hla expression in S. aureus in vitro. In addition, two sarA homologs, $\operatorname{rot}$ and $\operatorname{sar} T$, repress the hla expression. The agr locus affects a direct positive impact on hla expression, whereas sarA

(C) The Author(s). 2020 Open Access This article is licensed under a Creative Commons Attribution 4.0 International License, which permits use, sharing, adaptation, distribution and reproduction in any medium or format, as long as you give appropriate credit to the original author(s) and the source, provide a link to the Creative Commons licence, and indicate if changes were made. The images or other third party material in this article are included in the article's Creative Commons licence, unless indicated otherwise in a credit line to the material. If material is not included in the article's Creative Commons licence and your intended use is not permitted by statutory regulation or exceeds the permitted use, you will need to obtain permission directly from the copyright holder. To view a copy of this licence, visit http://creativecommons.org/licenses/by/4.0/. The Creative Commons Public Domain Dedication waiver (http://creativecommons.org/publicdomain/zero/1.0/) applies to the data made available in this article, unless otherwise stated in a credit line to the data. 
positively affects the hla expression via both agrdependent and $a g r$-independent pathways. The sae locus consists of a two-component signal transduction system, encoded by saeS (sensor) and saeR (response regulator), which positively controls the expression of hla at the transcriptional level. In addition, the complex transcriptional profile of sae activation is influenced by $a g r$, as well as by certain environmental stimuli, and may also be influenced by sigma factor B (sigB) [4].

The current antimicrobial therapy is still important for the treatment of pneumonia due to MRSA infection, but there are some limitations, including the route of administration, side effect profile, and most importantly, increased microbial resistance patterns [5]. Therefore, it is necessary to search materials that overcome the obstacles to the treatment of pneumonia caused by MRSA. Some researchers have already reported on the studies that is treatment of pneumonia by using natural product or peptide. Bae et al., reported that SAL200, which is peptidoglycan-degrading enzyme, reduced the pulmonary bacterial burden in MRSA induced pneumonia [6]. Xia et al., reported that the combination of LysGH15 (peptide) and apigenin (natural product) shows therapeutic potential for treating MRSA induced pneumonia [7]. Also, several researchers demonstrated that natural products target virulence and exhibit therapeutic effect against MRSA-induced pneumonia [8, 9]. We have also performed the study on treatment of pneumonia by using material used in traditional Eastern medicine.

Bee venom (BV) has been used in traditional Eastern medicine to reduce pain and treat chronic inflammatory diseases. Various studies have demonstrated the biological activity of BV. In addition, BV has been reported to have various physiological activities such as antibacterial, anticancer, and anti-inflammatory effects [10-12]. BV contains various peptides, amines, nonpeptide components, and free amino acids, which are presumed to have anti-inflammatory, analgesic, and anticancer effects. BV contains physiologically active peptides such as melittin, secapin, mast cell degranulating (MCD) peptide, apamin, etc. [13]. Melittin is a major component of the honey bee (Apis mellifera L.) venom and an amphiphilic peptide that has 26 amino acid residues. Melittin has been used in tumor-bearing mouse research because of its cytotoxicity to tumor cells and capacity to inhibit cell growth or induce apoptosis and necrosis [14]. Lee et al. have reported the therapeutic effects of melittin and its detailed mechanisms of action against several inflammatory diseases, including skin, nerve, liver, atherosclerosis, and arthritis [15]. Secapin is a polycationic peptide with 25 amino acid residues, which contains an intramolecular disulfide bridge; it represents approximately $0.5 \%$ of the dry weight of honeybee venom [16]. Lee et al. have demonstrated that secapin functions as an antifibrinolytic, anti-elastolytic, and antimicrobial agent in a manner similar to that of serine protease inhibitors [17]. In addition, BV has been reported to show an antibacterial effect on MRSA [18]. However, no pneumonia mouse model of MRSA has been reported. Therefore, we investigated whether BV, which shows a strong antimicrobial effect against MRSA, would be effective in a pneumonia model.

\section{Methods}

\section{Bacterial strains and reagents}

ATCC 33591 (reference strain, HA-MRSA) and USA300 (wild-type LAC strain, CA-MRSA) were used in this study. ATCC 33591 was incubated in Mueller-Hinton broth (MHB), and USA300 was incubated in tryptic soy broth (TSB) at $37^{\circ} \mathrm{C}$ for $24 \mathrm{~h}$. Bee venom (BV) which is collected by bee venom collector apparatus (Chunglin Biotech, Ansan, Korea) to natural honeybees (Apis mellifera L.) was purchased from Korea Purified bee venom agricultural association corporation (Changnyeong, korea). The contents of melittin, the main component of bee venom, were analyzed by UPLC (Agilent 1290, USA) according to $\mathrm{pH}$ and temperature changes. The analysis conditions are shown in Table 1 , and the results of the UPLC analysis are shown in Fig. 1. The content of melittin in bee venom was $60.2 \%$.

\section{Mouse model of intranasal lung infection}

Balb/c mice (7 weeks old, females) were purchased from Orient Bio (Seongnam, Korea). S. aureus USA300 was grown in TSB at $37^{\circ} \mathrm{C}$ to an optical density at $600 \mathrm{~nm}\left(\mathrm{OD}_{600}\right)$ of $0.6 ; 50 \mathrm{~mL}$ of the culture was centrifuged $(3000 \times \mathrm{g}$, room temperature, 5 $\mathrm{min}$ ), and the pellet was resuspended in $1.2 \mathrm{~mL}$ of sterile phosphate-buffered saline (PBS, pH 7.4). For both lethality and histopathology assays, the mice were randomly divided into seven groups (normal, PBS, control, BV 0.125, BV 0.25, BV 0.5 and LZD 10 $\mathrm{mg} / \mathrm{kg} /$ day groups; $n=5$ each) after intranasal infection with $30 \mu \mathrm{L}$ of an $S$. aureus suspension $\left[1 \times 10^{10}\right.$ colony-forming units $(\mathrm{CFU})$ per $30 \mu \mathrm{L}]$. After $30 \mathrm{~min}$, BV $(0.125,0.25$, and $0.5 \mathrm{mg} / \mathrm{kg} /$ day $)$ and LZD was administered by intraperitoneal injection. The control group mice were treated with $100 \mu \mathrm{L}$ of sterile PBS on the same schedule as a solvent control. For histopathological analysis, the mice were anesthetized and euthanized by cervical dislocation $24 \mathrm{~h}$ post-infection. Ketamine (10 mg / mL) / Xylazine (10 mg / mL) was used for mouse anesthesia and administered $10 \mu \mathrm{L} / \mathrm{g}$ by intraperitoneal injection The lungs were fixed in $10 \%$ formaldehyde, stained with hematoxylin and eosin (H\&E), and examined by light microscopy. 
Table 1 UPLC conditions for melittin analysis

\begin{tabular}{|c|c|c|c|}
\hline Item & \multicolumn{3}{|l|}{ Condition } \\
\hline Column & \multicolumn{3}{|c|}{ Halo ES-C18(2.1 × 100 mm, $2.7 \mu \mathrm{m}$, Advanced materials technology, USA) } \\
\hline Flow rate & \multicolumn{3}{|l|}{$0.8 \mathrm{~mL} / \mathrm{min}$} \\
\hline Column temperature & \multicolumn{3}{|l|}{$50^{\circ} \mathrm{C}$} \\
\hline Injection volume & \multicolumn{3}{|l|}{$2 \mu l$} \\
\hline Wavelength & \multicolumn{3}{|l|}{$220 \mathrm{~nm}$} \\
\hline \multirow[t]{3}{*}{ Mobile phase } & Time (min) & $20 \mathrm{mM} \mathrm{TFA} / \mathrm{MeCN}(\%)$ & $20 \mathrm{mM} \mathrm{TFA} / \mathrm{H}_{2} \mathrm{O}(\%)$ \\
\hline & 0 & 40 & 60 \\
\hline & 6 & 45 & 55 \\
\hline
\end{tabular}

${ }^{\mathrm{a}}$ TFA trifluoroacetic acid

The measurement of minimum inhibitory concentration (MIC)

The minimum inhibitory concentration (MIC) was determined using a broth microdilution method according to the Clinical and Laboratory Standards Institute guidelines [19]. Serial, two-fold dilutions of BV and $10 \mu \mathrm{L}$ of antibiotics were prepared in $100 \mu \mathrm{L}$ of MHB and TSB in 96-well microplates. The microplates were inoculated with MRSA adjusted to 0.5 McFarland standard (approximately $10 \mu \mathrm{L}$ of $1.5 \times 10^{8} \mathrm{CFU} / \mathrm{mL}$; final density $\left.1.5 \times 10^{6} \mathrm{CFU} / \mathrm{mL}\right)$. MIC was determined as the lowest BV concentration suppressing the growth of MRSA after $24 \mathrm{~h}$ of incubation at $37^{\circ} \mathrm{C}$.

\section{RNA extraction and quantitative reverse transcription} polymerase chain reaction (qRT-PCR)

Total RNA was isolated from ATCC 33591 using an E.Z.N.A. ' bacterial RNA kit (Omega Bio-tek, Norcross, GA, USA) according to the manufacturer's instructions. Total RNA was also isolated from homogenized lung tissue using an easy-BLUE ${ }^{\mathrm{T}}$ total RNA extraction kit (iNtRon Biotechnology, Inc., Seongnam, Korea). Total RNA was dissolved in diethyl pyrocarbonate-treated distilled water. A spectrophotometer (BioTek, Winooski, VT, USA) was used to evaluate RNA purity by measuring the absorbance ratio at 260 and $280 \mathrm{~nm}$. Complementary
DNA was synthesized using the QuantiTect reverse transcription kit (Qiagen, Seoul, Korea) according to the manufacturer's instructions. Real-time quantitative reverse transcription-polymerase chain reaction (qRTPCR) was performed in triplicate using a Power $\mathrm{SYBR}^{\circ}$ Green PCR master mix (Applied Biosystems, Foster City, CA, USA) and a StepOnePlus real-time PCR system (Applied Biosystems). The amplification conditions were $95^{\circ} \mathrm{C}$ for $10 \mathrm{~min}$, followed by 40 cycles of $95^{\circ} \mathrm{C}$ for $15 \mathrm{~s}$ and $60{ }^{\circ} \mathrm{C}$ for $1 \mathrm{~min}$. Expression levels of target genes relative to the endogenous reference gene, $\beta$-actin, were calculated by the delta-delta cycle threshold method using the StepOne software v2.3 (Applied Biosystems). The primer sequences are listed in Table 2.

\section{Western blot analysis}

MRSA strain ATCC 33591 was grown to an $\mathrm{OD}_{600}$ value of 0.9 in $\mathrm{MHB}$ with various concentrations of $\mathrm{BV}$ for western blotting, and the cells were harvested after $4 \mathrm{~h}$ of treatment by centrifugation at $13,000 \mathrm{rpm}$ for $10 \mathrm{~min}$. The harvested bacterial cells were resuspended in the SMART bacterial protein extraction solution (iNtRON Biotechnology) according to the manufacturer's protocol. Denatured protein lysates $(20 \mu \mathrm{L})$ were separated by $12 \%$ sodium dodecyl sulfate polyacrylamide gel electrophoresis, and the resolved proteins were transferred onto

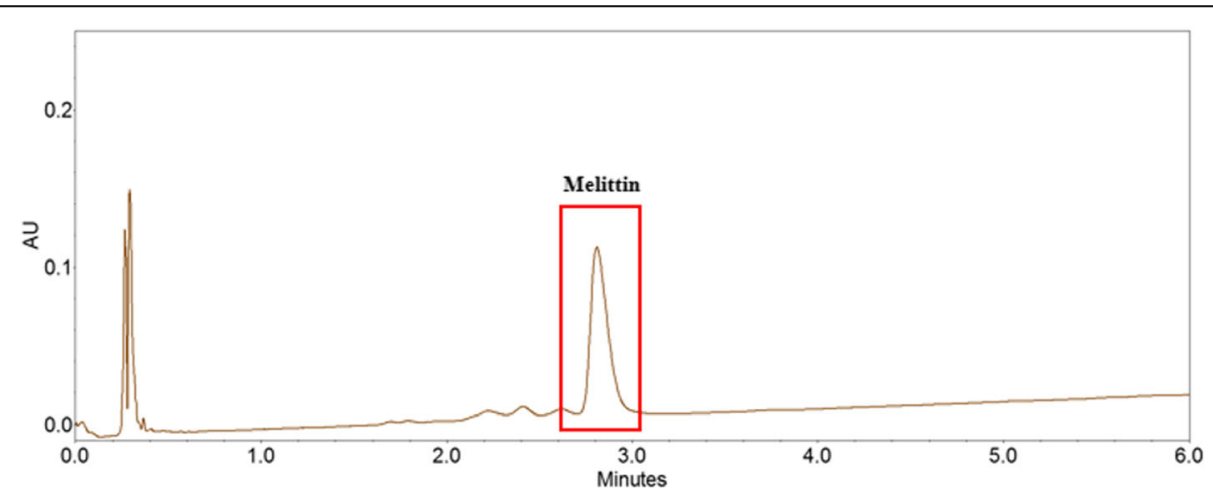

Fig. 1 Measurement of melittin content in bee venom using UPLC analysis 
Table 2 Sequences of oligonucleotide primers designed for real-time PCR

\begin{tabular}{|c|c|}
\hline Gene & Primer sequence \\
\hline \multicolumn{2}{|l|}{$\overline{S a a 3}$} \\
\hline Forward & GCCTGGGCTGCTAAAGTCAT \\
\hline Reverse & TGCTCCATGTCCCGTGAAC \\
\hline \multicolumn{2}{|l|}{ Orm1 } \\
\hline Forward & GTGTGTCTATAACTCCACCCATC \\
\hline Reverse & CCCATGTTTCCTCAGCACTAT \\
\hline \multicolumn{2}{|l|}{ CXCL9 } \\
\hline Forward & GGCACGATCCACTACAAATCC \\
\hline Reverse & GGTTTGATCTCCGTTCTTCAGT \\
\hline \multicolumn{2}{|l|}{ Pon1 } \\
\hline Forward & GGACTAACTTTCTITAGCATGGGC \\
\hline Reverse & TTCTAACTCTGACACTGCTGGCTCC \\
\hline \multicolumn{2}{|l|}{ GAPDH } \\
\hline Forward & TGGGCTACACTGAGCACCAG \\
\hline Reverse & GGGTGTCGCTGTTGAAGTCA \\
\hline \multicolumn{2}{|l|}{ hla } \\
\hline Forward & TTGGTGCAAATGTTTC \\
\hline Reverse & TCACTTTCCAGCCTACT \\
\hline \multicolumn{2}{|l|}{ agra } \\
\hline Forward & TGATAATCCTTATGAGGTGC \\
\hline Reverse & CACTGTGACTCGTAACGAAA \\
\hline \multicolumn{2}{|l|}{16 S RRNA } \\
\hline Forward & CGTGCTACAATGGACAATAC \\
\hline Reverse & ATCTACGATTACTAGCGATT \\
\hline
\end{tabular}

polyvinylidene difluoride membranes. The membranes were incubated with an anti-Staphylococcus alpha hemolysin antibody (diluted 1:500; Abcam, UK) overnight at $4{ }^{\circ} \mathrm{C}$. Goat anti-rabbit IgG (diluted 1:1000; Thermo Scientific, USA) diluted 1:2500 in 5\% skim milk was used as a secondary antibody. Immunoreactive protein bands were detected using the EzWestLumi Plus luminol substrate (ATTO Co., Tokyo, Japan) and visualized using an ImageQuant LAS $4000 \mathrm{mini}$ chemical luminescent imager (GE Healthcare Life, Korea).

\section{Enzyme-linked immunosorbent assay (ELISA)}

The MRSA was grown to an $\mathrm{OD}_{600}$ value of 0.9 in $\mathrm{MHB}$ with various concentrations of BV for ELISA. Preparation of RAW 264.7 cells were prepared in RPMI 1640 (supplementedwith $10 \% \mathrm{FBS}, 100 \mathrm{IU} / \mathrm{mL}^{-1}$ penicillin and streptomycin). Cells were seeded at a density of $10^{6} \%$ $\mathrm{mL}$ in RPMI, dispensed $(100 \mu \mathrm{L})$ into 96 -well tissue culture plates and then incubated in $5 \% \mathrm{CO}_{2}$ at $37^{\circ} \mathrm{C}$ in an incubator for $18 \mathrm{~h}$ to allow adherence. Cell culture media were washed and RPMI 1640 medium $(150 \mu \mathrm{L})$ was added. Staphylococcus aureus supernatants $(50 \mu \mathrm{L})$ were added to the tissue culture plate. After incubation for $16 \mathrm{~h}$, supernatants were collected, centrifuged (1000 $\mathrm{g}$ for $5 \mathrm{~min})$. Cytokines in the supernatant were measured using the OptEIATM human enzyme-linked immunosorbent assay (ELISA; BD Bioscience, San Jose, CA, USA). Each well of the 96-well microplate was coated with capture antibody diluted in coating buffer (0.1 M carbonate, pH 9.5). Each plate was sealed and incubated overnight at $4{ }^{\circ} \mathrm{C}$. After washing three times with phosphate buffered saline (PBS) containing $0.05 \%$ Tween 20, nonspecific binding sites were blocked with PBS containing 10\% FBS ( $\mathrm{pH} 7.0$ ) for $1 \mathrm{~h}$. One hundred microliters of each sample, TNF- $\alpha$ and IL- 6 standards were added to wells and incubated for $2 \mathrm{~h}$ at room temperature. One hundred microliters of detection antibody conjugated with and avidin-horseradish peroxidase (HRP) diluted in assay buffer was applied for $1 \mathrm{~h}$. One hundred microliters of substrate solution (tetramethylbenzidine, TMB) was added to each wells and incubated for $30 \mathrm{~min}$ at room temperature in the dark. The $50 \mu \mathrm{L}$ of stop solution $\left(2 \mathrm{M} \mathrm{H}_{2} \mathrm{SO}_{4}\right)$ was added and the absorbance was determined at $450 \mathrm{~nm}$.

\section{Cell viability and lactate dehydrogenase assays}

A549 human lung epithelial cells were cultured in Dulbecco's modified Eagle's medium (DMEM) supplemented with $10 \%$ heat-inactivated fetal bovine serum (Welgene, Inc., Korea) and $100 \mu \mathrm{g} / \mathrm{mL}$ penicillin. Cell viability was evaluated by an MTS [3-(4,5-dimethylthiazol-2-yl)-5-(3-carboxymethoxyphenyl)-2-(4-sulfophenyl)-2H-tetrazolium] assay (Promega, Madison, WI, USA) following the incubation in the presence of BV for $24 \mathrm{~h}$ at the aforementioned temperature in an atmosphere containing $5 \% \mathrm{CO}_{2}$. The plate was read using an Epoch microplate spectrophotometer (BioTek), and the absorbance was measured at $490 \mathrm{~nm}$. To detect the lactate dehydrogenase (LDH) activity, A549 cells were seeded at $1.5 \times 10^{4}$ cells per well, cultivated for $12 \mathrm{~h}$ to attach, and then incubated with a bacterial suspension at $37^{\circ} \mathrm{C}$ for $6 \mathrm{~h}$ in DMEM without fetal bovine serum (6). Cytotoxicity was determined based on the $\mathrm{LDH}$ release using a Pierce LDH cytotoxicity assay kit (Thermo Scientific, USA) according to the manufacturer's directions and measuring absorbance on a spectrophotometer (BioTek).

\section{Lung bacterial clearance assay}

In the sublethal model, lungs were harvested after the mice were euthanized, and lung tissue was homogenized in $1 \mathrm{~mL}$ of sterile PBS. Serial dilutions were prepared in PBS and plated on tryptic soy agar plates. After $24 \mathrm{~h}$ of incubation, bacterial colonies were counted, and CFU counts per milliliter of a lung homogenate were calculated. 


\section{Statistical analysis}

Data from the experiments are presented as the mean \pm SEM. The level of statistical analysis was performed by Scheffe's test (SPSS. ver.23) for multiple comparisons. Pvalues $<0.05$ was considered significant.

\section{Results}

Minimum inhibitory concentration (MIC) against MRSA

The MIC values of BV and LZD against the two strains, ATCC 33591 and USA300, are presented in Table 3. The growth of $S$. aureus was inhibited at a concentration of $15.6 \mu \mathrm{g} / \mathrm{mL} \mathrm{BV}$. The MIC of BV was almost similar to that of LZD, a strong antibiotic used to treat MRSA. This results showed that BV have antibacterial activity against MRSA.

The inhibition effect of BV against toxins production and related gene of MRSA

Expression of the hla and agrA genes, related to $\alpha$ hemolysin was confirmed by qRT-PCR. Expression of the four genes was significantly suppressed in ATCC 33591 by the treatment with serial dilutions of BV. In particular, the expression of agrA was inhibited when treated with BV than treated with LZD (Fig. 2). Western blotting was used to investigate the effect of BV on toxin production by MRSA. Production of $\alpha$-hemolysin by ATCC 33591 was significantly decreased by the treatment with serial dilutions of BV. The expression of the toxin showed a similar degree of inhibition when treated with BV compared with LZD treatment (Fig. 3).

Effects of BV in the pro-inflammatory cytokine release of 264.7 RAW macrophages stimulated by MRSA

ELISA was used to evaluate the effect of BV in tumor necrosis factor (TNF)- $\alpha$ and interleukin (IL)- 6 secretion of 264.7 RAW macrophages stimulated by MRSA. The secretion of two cytokines in macrophages significantly increased after stimulation of MRSA. However, the secretion of these cytokines were decreased by treatment with either concentration of BV (Fig. 4).

\section{Effects of BV on cell viability from virulence of MRSA}

The MTS assay was performed to measure the viability of A549 human lung epithelial cells treated with BV. BV did not affect the viability of A549 cells at concentrations below $6.25 \mu \mathrm{g} / \mathrm{mL}$ (Fig. 5a). Therefore, the LDH

Table 3 The MIC of BV and LZD against MRSA

\begin{tabular}{lll}
\hline S. aureus & MIC $(\mu \mathrm{g} / \mathrm{ml})$ & \\
\cline { 2 - 3 } strain & BV & LZD \\
\hline ATCC33591 & $15.2 \pm 3.2^{\mathrm{a}}$ & $7.8 \pm 1.5$ \\
USA300 & $15 \pm 4.4$ & $15.6 \pm 2.1$ \\
\hline
\end{tabular}

${ }^{\mathrm{a}}$ Mean of triplicate, with standard deviation assay was performed to examine whether BV protects cells from MRSA at concentrations below $6.25 \mu \mathrm{g} / \mathrm{mL}$. As a result, it was demonstrated that the LDH level decreased in a concentration-dependent manner upon BV treatment (Fig. 5b).

\section{Therapeutic effect of BV against MRSA-induced pneumonia}

Mouse survival rates were determined after intraperitoneal administration of BV to pneumonia-induced model mice. As a result, it was found that $20 \%$ of the mice survived in the BV 0.125 and $0.25 \mathrm{mg} / \mathrm{kg}$ groups, and $60 \%$ survived in the BV 0.5 and LZD $10 \mathrm{mg} / \mathrm{kg}$ group (Fig. 6). Gross pathological change and $H \& E$ staining of lung tissues is shown in Fig. 7. Compared to the PBS group, more inflammation, with pulmonary edema, multifocal bacterial aggregates, and lung structure destruction, was observed in the lungs of the MRSA-infected mice. With BV treatment, no abscesses were formed, lung edema was less pronounced, and fewer inflammatory cells were observed compared to those observed without BV treatment (Fig. 7). To confirm the lung bacterial clearance, lungs of infected mice were homogenized, and then the number of bacterial cells was counted. As a result, it was shown that the number of bacterial cells decreased from $10^{8}$ to $10^{4} \mathrm{CFU} / \mathrm{mL}$ at the maximum. When $0.5 \mathrm{mg} / \mathrm{kg}$ $\mathrm{BV}$ was treated, the number of bacteria was about 10 times smaller than that of $10 \mathrm{mg} / \mathrm{kg}$ LZD treatment (Fig. 8).

The effect of BV in inflammation-related gene expression in a lung infection model

qRT-PCR was performed to evaluate the gene expression in lung tissue. Compared to their levels of expression in the PBS group, the serum amyloid A3 (Saa3), chemokine ( $\mathrm{C}-\mathrm{X}-\mathrm{C}$ motif) ligand 9 ( $\mathrm{Cxcl} 9)$, and orosomucoid 1 (Orm1) genes were significantly upregulated, while the paraoxonase 1 (Pon1) gene was significantly downregulated in the lungs after MRSA infection. However, expression of Saa3, Cxcl9, and Orm1 decreased and that of Pon1 increased in the BV-treated group compared to that in the BV-free MRSA infection group (Fig. 9).

\section{Discussion}

Pneumonia is one of the most serious infectious diseases with high morbidity and mortality. Children below the age of 5 and seniors over the age of 65 are more susceptible to developing severe pneumonia, owing to their weaker immune systems. The emergence of drugresistant bacteria complicates the empirical treatment of pneumonia. For example, penicillin resistance has become widespread, and patients with MRSA pneumonia have a higher risk of treatment failure [20]. New 

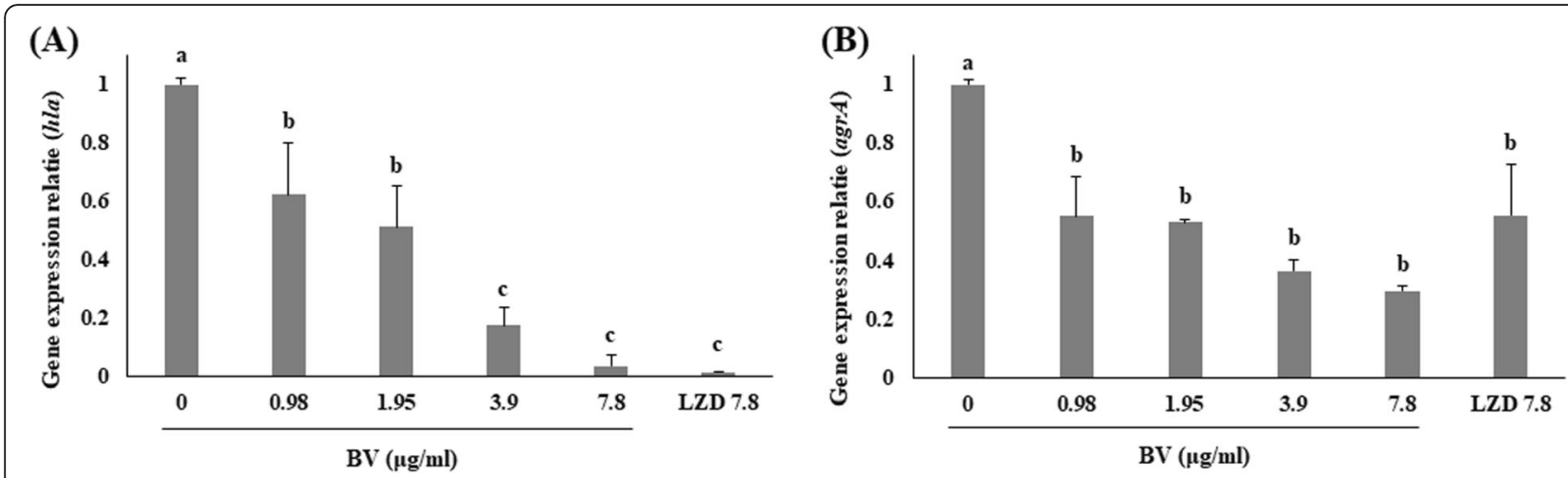

Fig. 2 Effects of BV on the mRNA expression of hla and agrA, as analyzed by qRT-PCR. Cells of ATCC 33591 were treated with serial dilutions of BV $(0.98,1.95,3.9$, and $7.8 \mu \mathrm{g} / \mathrm{mL})$ and $7.8 \mu \mathrm{g} / \mathrm{mL}$ LZD for $4 \mathrm{~h}$. Different letters (a-d) indicate significant differences at the $p<0.05$ level, according to analysis of variance followed by Scheffe's test for multiple comparisons $(p<0.05)$. Values are means \pm standard errors

antibacterial agents are urgently needed to combat this crisis, and natural products are important sources for new antibiotics. BV contains various peptides, amines, nonpeptide components, and free amino acids, which show anti-inflammatory, analgesic, and anticancer effects, such as melittin, secapin, MCD peptide, apamin, etc. [10-13]. BV has been reported to exhibit antimicrobial activity against MRSA, and its main constituent, melittin, has also been reported to show antimicrobial activity against MRSA. Therefore, we expected that BV would be effective against pneumonia caused by MRSA infection.
BV showed antimicrobial activity against MRSA and a significant bactericidal effect at relatively low concentrations (Table 3). This data showed that BV can be an effective antibiotic in the treatment of MRSA infections. The $\alpha$-hemolysin is toxic substances produced by $S$. aureus and is virulence factors of infectious diseases caused by MRSA [21]. The toxin secreted by $S$. aureus causes tissue damage, promote bacterial dissemination and metastatic growth in distant organs, and enable the pathogen to evade the host innate immune response [22]. Expression of the toxin, an important factor in the pathogenicity of MRSA, was found to decrease when

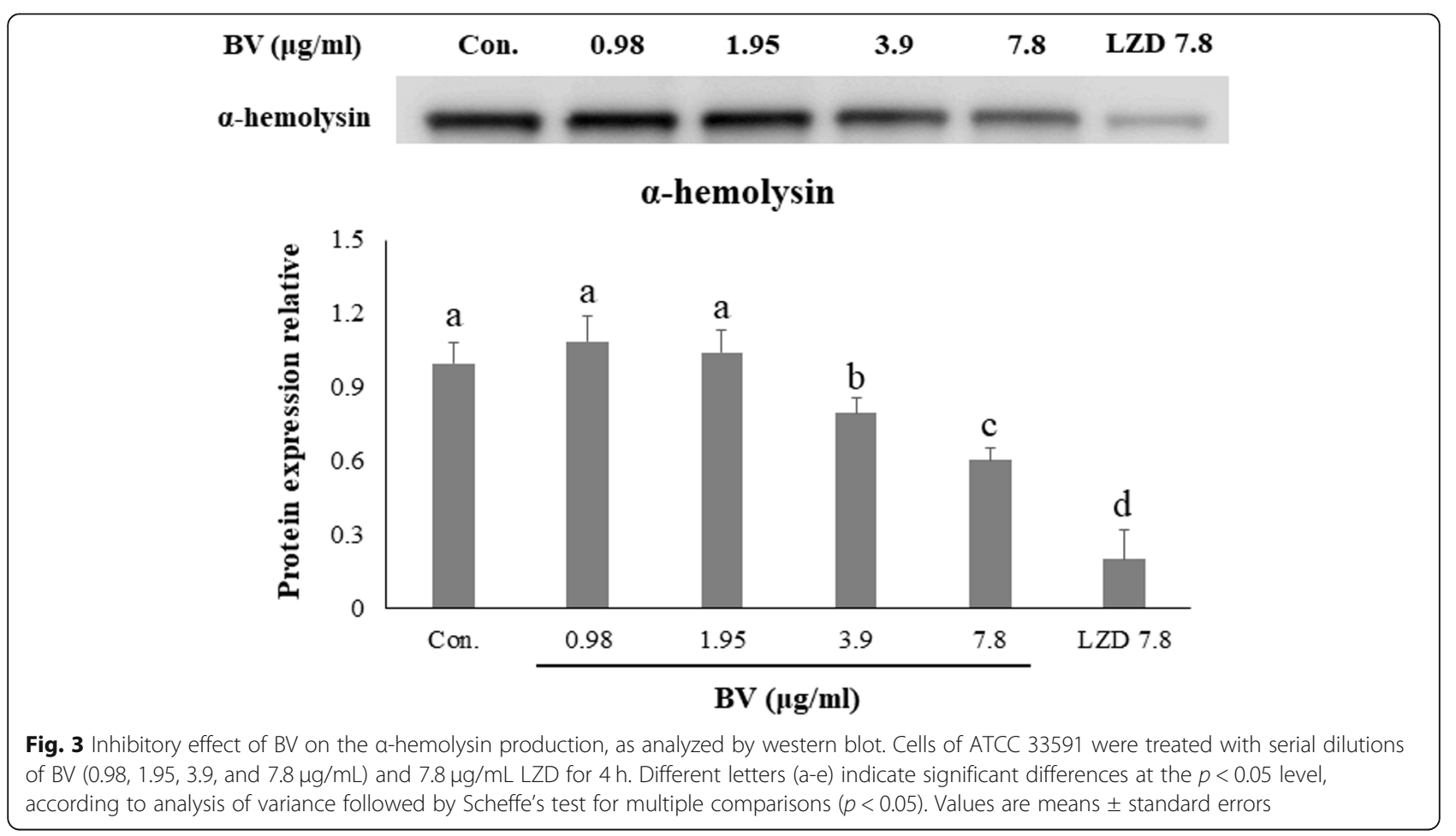



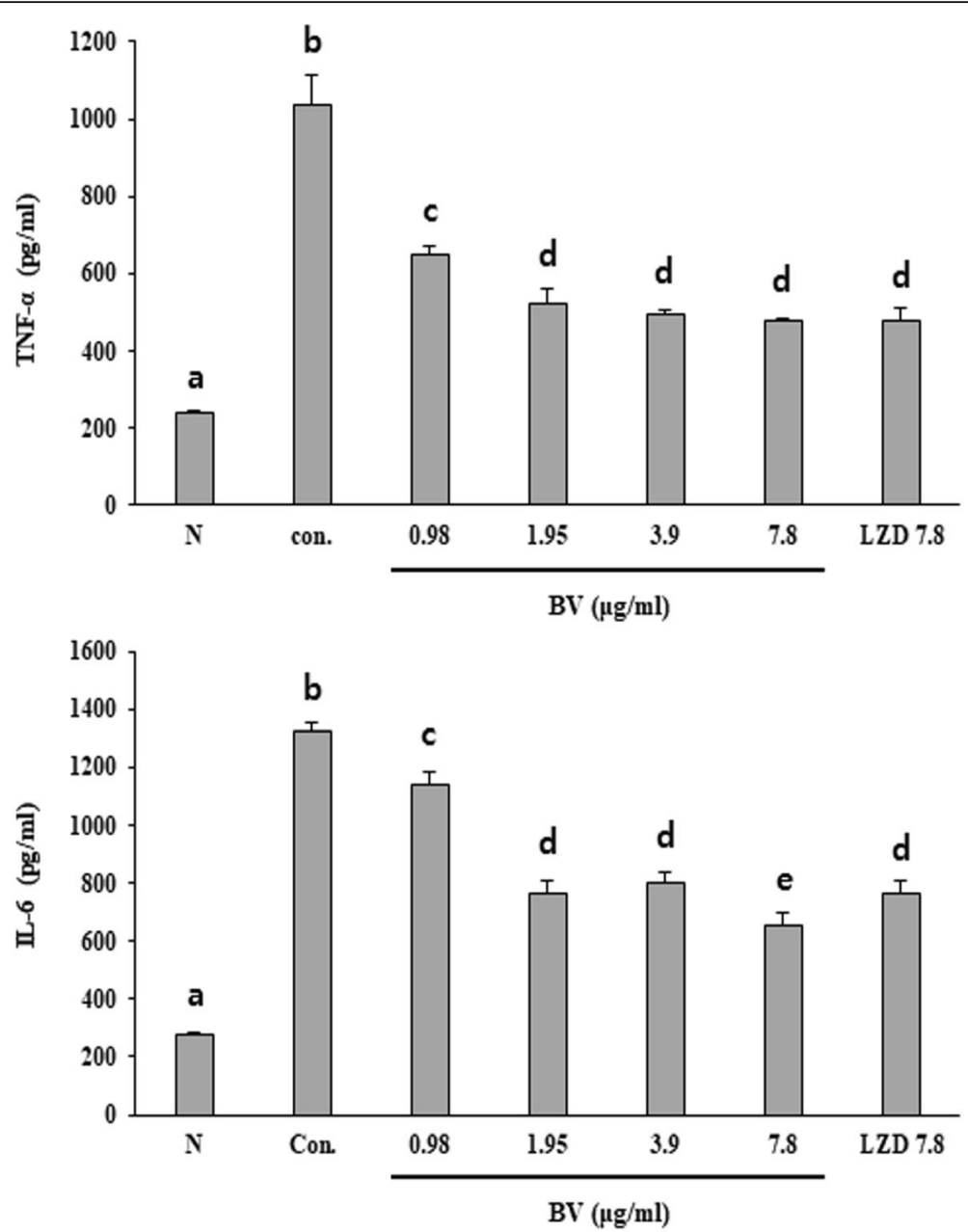

Fig. 4 Effect of BV in TNF-a and IL-6 secretion of 264.7 RAW macrophages stimulated by MRSA. After stimulation for $16 \mathrm{~h}$ with supernatants of S. aureus grown in the presence of graded concentrations of BV in RAW 264.7 cells, TNF-a and IL-6 levels were measured by ELISA. Different letters (a-e) indicate significant differences at the $p<0.05$ level, according to analysis of variance followed by Scheffe's test for multiple comparisons $(p<$ 0.05). Values are means \pm standard errors

bacterial cells were treated with BV (Fig. 3). The secretion of TNF- $\alpha$ and IL- 6 was decreased by BV in inflammatory response 264.7 RAW macrophages stimulated by MRSA (Fig. 4). These results suggested that BV reduces the pathogenicity by decreasing toxin production by MRSA. It was also shown that the survival rate of A549 cells treated with BV increased (Fig. 6). The hla gene encodes $\alpha$-hemolysin. This gene is regulated by agrA. The agr quorum sensing, an important bacterial regulatory system that relies on the detection of extracellular autoinducers, has been shown to control the virulence of many bacterial pathogens, including regulation of $\alpha$ hemolysin. In S. aureus, the agr quorum sensing is responsible for the increased expression of virulence genes, including those encoding many toxins and degradative exoenzymes, which are essential for the establishment of infection [23-26]. The results presented in Fig. 2 showed that BV decreased the hla and agrA expression in MRSA. The data suggested that BV possessed antibacterial activity and inhibited the virulence of MRSA because of the reduction of toxin production and related gene expression.

The primary aim of this study was to examine the effect of BV in a pneumonia model induced by MRSA infection. Survival rates were increased by administering BV to MRSA-induced pneumonia mice (Fig. 6). The BVtreated group showed a recovery of the lung structure destruction and a decrease of multifocal bacterial aggregates and pulmonary edema (Fig. 7.). In addition, when mice were treated with BV, the number of bacterial cells present in the lungs was reduced (Fig. 8). The $\alpha$ hemolysin, a pore-forming cytolytic toxin, has been shown to be a key virulence determinant in S. aureus-induced pneumonia mouse models [27]. By inhibiting the 

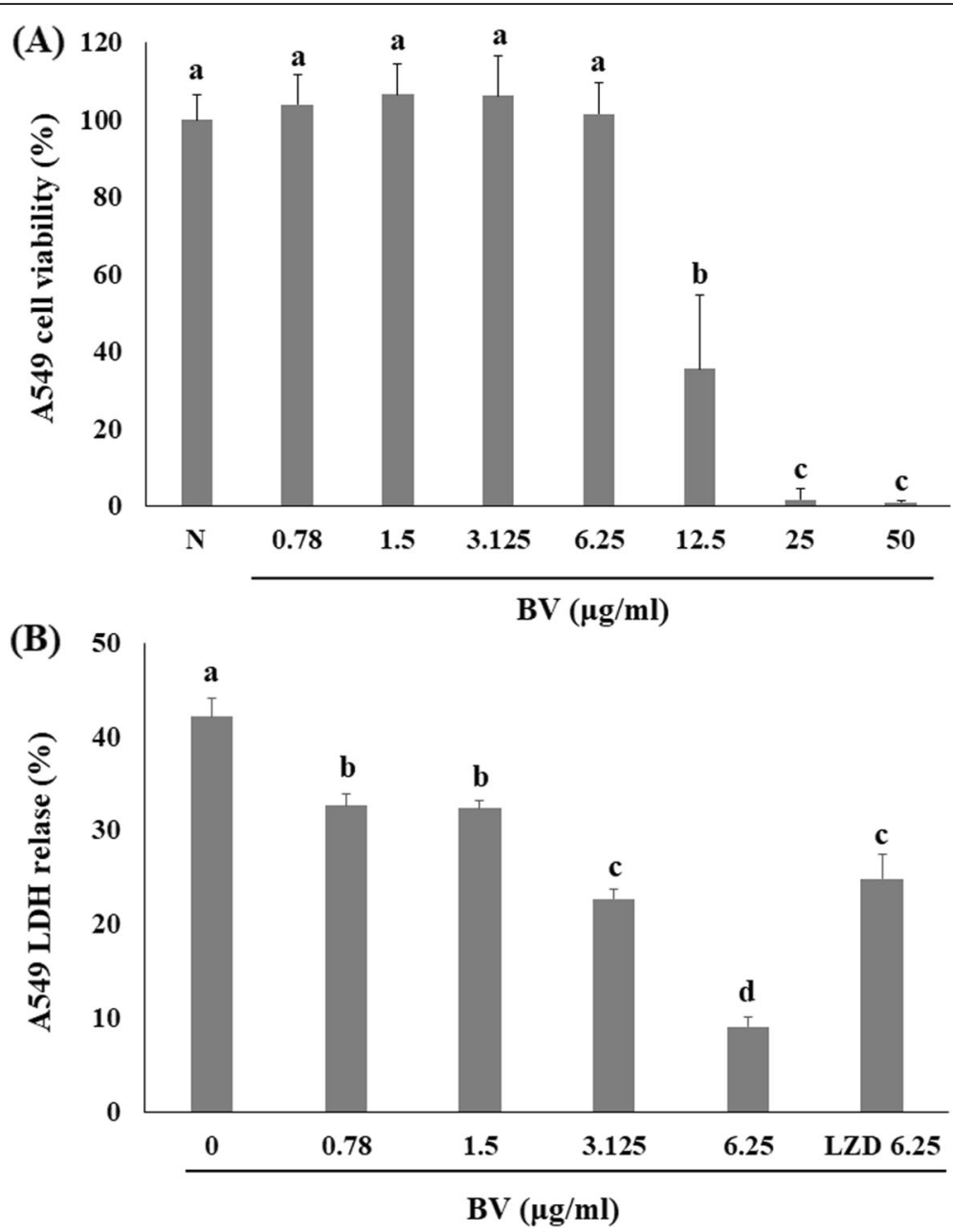

Fig. 5 BV attenuates a-toxin-mediated injury of human alveolar epithelial cells. a Effects of BV on the viability of A549 cells were evaluated using the MTS assay. $\mathbf{b}$ The LDH release was determined using A549 cells co-cultured with USA300 and supplemented with the indicated concentrations of BV. Different letters (a-d) indicate significant differences at the $p<0.05$ level, according to analysis of variance followed by Scheffe's test for multiple comparisons $(p<0.05)$. Values are means \pm standard errors

production and activity of $\alpha$-hemolysin in MRSA, it is possible to alleviate the pneumonia caused by the infection. BV reduced the expression levels of $\alpha$-hemolysin and the hla gene, which encodes $\alpha$-hemolysin, in MRSA. This result suggested that BV protects lung tissue from the pathogenicity of MRSA.

We also confirmed the expression of inflammatory genes in pneumonia. Serum amyloid A-3 (SAA3) is an acute phase response protein whose transcription is strongly induced by endotoxin-induced lung inflammation [28]. Chemokine ligand 9 (CXCL9) is a small cytokine belonging to the CXC chemokine family, which is induced by inflammatory responses and is also known to be induced by pulmonary inflammation [29]. Orm1 is a gene encoding the orosomucoid 1 (ORM1) protein, which is classified as an acute phase protein and is increased by an acute inflammatory reaction [30]. Pon1 is a gene encoding paraoxonase 1 (PON1). Paraoxonases have been found to be show a number of biological functions such as anti-inflammatory, antioxidative, antimicrobial, and organophosphate-hydrolyzing activities. Sepsis caused by MRSA may contribute to an oxidative environment, which may result in increased binding of free radicals to PON1, leading to a reduction in PON1 activity in the circulation [31]. Our results showed that the expression of Saa3, Cxcl9, and Orm1 in the BV-treated group was reduced compared to that in the untreated group. However, the expression level of Pon1 in the BV-treated group increased compared to that in the untreated group (Fig. 9). These results suggested that the inflammatory reaction was alleviated in pneumonia-induced lung tissue because of decrease of virulence factor by BV. 


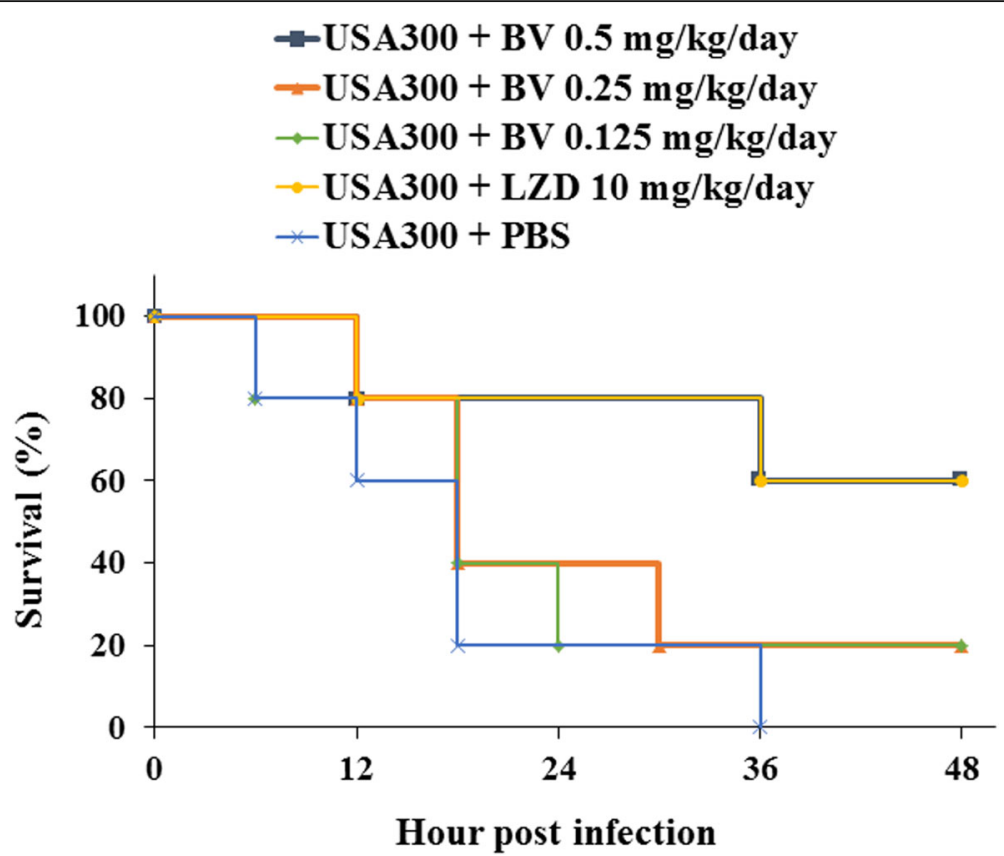

Fig. 6 Protection of model mice against MRSA-induced pneumonia by BV. Groups $(n=5)$ of mice were infected with USA300, and survival of the mice was monitored for $48 \mathrm{~h}$ after BV and LZD treatment

\section{Conclusion}

In summary, BV showed antibacterial activity against MRSA and inhibited toxin production. These activities of $\mathrm{BV}$ reduce the virulence of the bacterium and the number of bacterial cells present in lung tissue, thereby alleviating the symptoms of pneumonia in mice. This study suggested that BV may be a candidate substance for the treatment of pneumonia caused by MRSA infection. We plan to study the mechanism of this activity and various physiological activities of BV in the future.






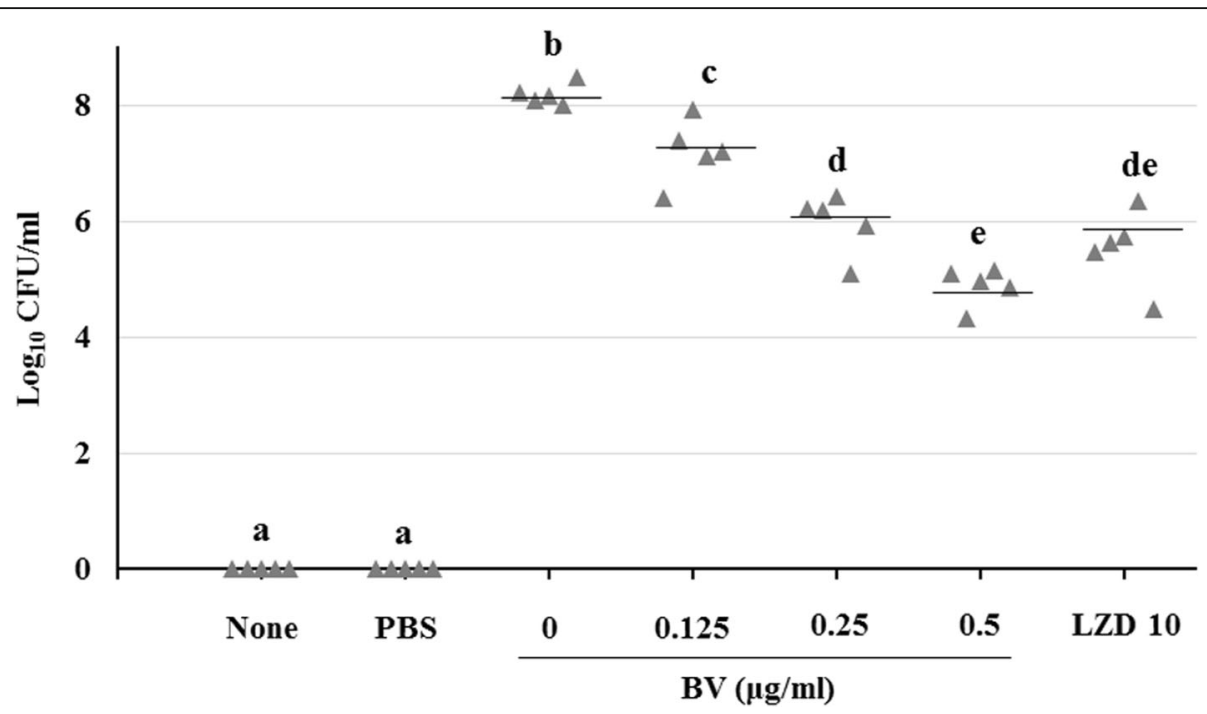

Fig. 8 Lung bacterial clearance with various BV concentrations in the MRSA-induced pneumonia model. Bacterial clearance was evaluated at $24 \mathrm{~h}$ post-MRSA infection in a mouse sublethal model of MRSA pneumonia. Different letters (a-e) indicate significant differences at the $p<0.05$ level, according to analysis of variance followed by Scheffe's test for multiple comparisons $(p<0.05)$. Values are means \pm standard errors

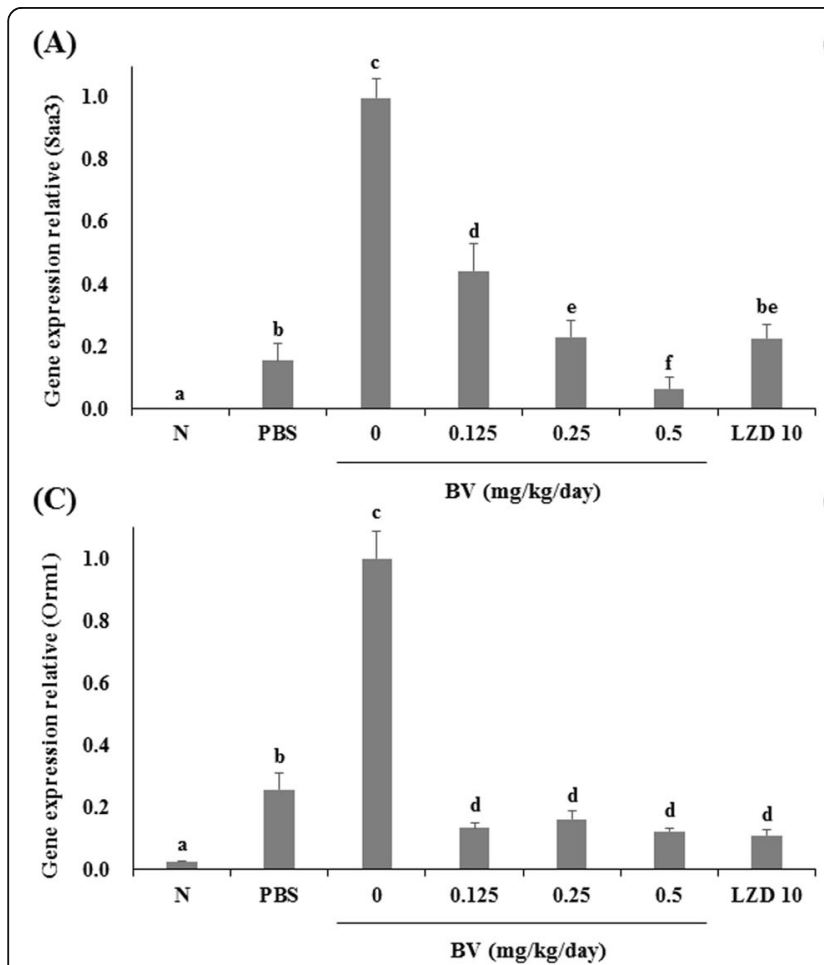

(B)

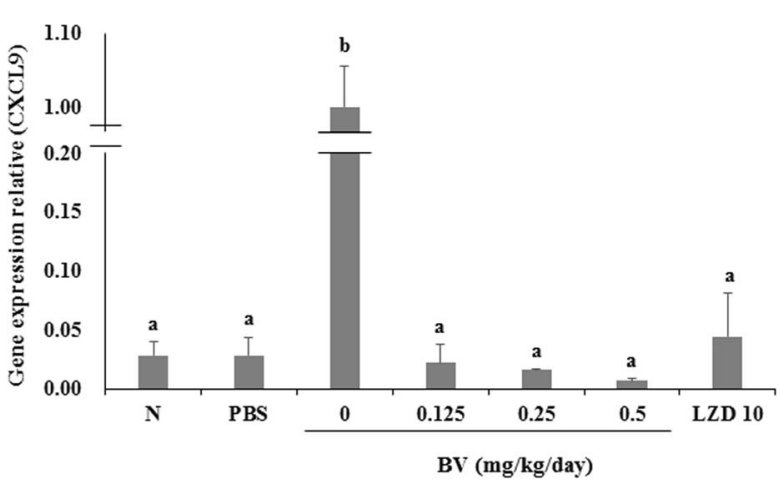

(D)

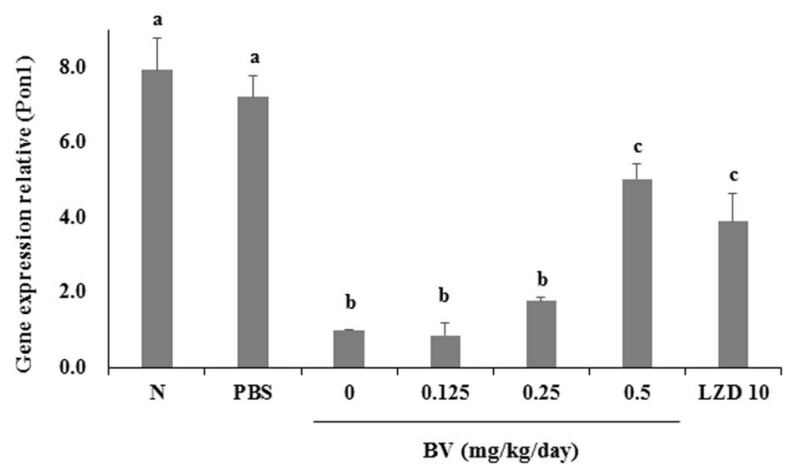

Fig. 9 Effects of BV on mRNA expression after lung infection with MRSA. Three genes (Saa3, Cxc19, and Orm1) were upregulated, and Pon1 was downregulated upon pneumonia. Different letters (a-f) indicate significant differences at the $p<0.05$ level, according to analysis of variance followed by Scheffe's test for multiple comparisons $(p<0.05)$. Values are means \pm standard errors 


\section{Supplementary information}

Supplementary information accompanies this paper at https://doi.org/10. 1186/s12906-020-02991-8.

\section{Additional file 1}

\section{Abbreviation}

BV: Bee venom; MRSA: Methicillin-resistant Staphylococcus aureus; hla: a hemolysin; LZD: Linezolid; MIC: Minimum inhibitory concentration; MHB: Mueller-Hinton broth; TSB: Tryptic soy broth; LDH: Lactate dehydrogenase

\section{Acknowledgements}

Not applicable.

\section{Authors' contributions}

Design of the work: RK, OHK and DYK. The acquisition of data: RK, YSL, DHK, SW and QQL. Analysis and interpretation of the data: YSL, DHK, SW and QQL. Wrote the paper: RK. Revise the parper: OHK and DYK. All authors have read and approved the manuscript.

\section{Funding}

This research was supported by Wonkwang University in 2018.

\section{Availability of data and materials}

The datasets used and/or analysed during the current study available from the corresponding author on reasonable request

\section{Ethics approval and consent to participate}

All animal experiments were conducted in accordance with the guidelines established by the Animal Ethics Committee of Wonkwang University, which also approved the protocols (Approval No. WKU17-04).

\section{Consent for publication}

Not applicable.

\section{Competing interests}

The authors declare that they have no competing interests.

\section{Author details}

${ }^{1}$ Department of Oriental Pharmacy, College of Pharmacy and Wonkwang-Oriental Medicines Research Institute, Wonkwang University, Iksan, Jeonbuk 54538, Republic of Korea. ${ }^{2}$ Department of Herbal Crop Research, National Institute of Horticultural \& Herbal Science, RDA, 92 Bisanro, Eumsung, Chungbuk 27709, Republic of Korea.

\section{Received: 20 May 2019 Accepted: 16 June 2020}

\section{Published online: 27 July 2020}

\section{References}

1. Torre-Cisneros J, Natera C, Mesa F, Trikic M, Rodríguez-Baño J. Clinical predictors of methicillin-resistant Staphylococcus aureus in nosocomial and healthcare-associated pneumonia: a multicenter, matched case-control study. Eur J Clin Microbiol Infect Dis. 2018;37(1):51-6.

2. Ohlsen K, Koller KP, Hacker J. Analysis of expression of the alpha-toxin gene (hla) of Staphylococcus aureus by using a chromosomally encoded hla::lacz gene fusion. Infect Immun. 2017;65(9):3606-14.

3. Bubeck Wardenburg J, Patel RJ, Schneewind O. Surface proteins and exotoxins are required for the pathogenesis of Staphylococcus aureus pneumonia. Infect Immun. 2007;75(2):1040-4.

4. Xiong YQ, Willard J, Yeaman MR, Cheung AL, Bayer AS. Regulation of Staphylococcus aureus alpha-toxin gene (hla) expression by agr, sarA, and sae in vitro and in experimental infective endocarditis. J Infect Dis. 2016; 194(9):1267-75. https://doi.org/10.1086/508210

5. Politano AD, Sawyer RG. NXL-103, a combination of flopristin and linopristin, for the potential treatment of bacterial infections including communityacquired pneumonia and MRSA. Curr Opin Investig Drugs. 2010;11(2):22536.

6. Bae JY, Jun KI, Kang CK, Song KH, Choe PG, Bang JH, Kim ES, Park SW, Kim HB, Kim NJ, Park WB, Oh MD. Efficacy of Intranasal Administration of the
Recombinant Endolysin SAL200 in a Lethal Murine Staphylococcus aureus Pneumonia Model. Antimicrob Agents Chemother. 2019;63(4). https://doi. org/10.1128/AAC.02009-18.

7. Xia F, Li X, Wang B, Gong P, Xiao F, Yang M, Zhang L, Song J, Hu L, Cheng M, Sun C, Feng X, Lei L, Ouyang S, Liu ZJ, Li X, Gu J, Han W. Combination therapy of LysGH15 and Apigenin as a new strategy for treating pneumonia caused by Staphylococcus aureus. Appl Environ Microbiol. 2015;82(1):87-94.

8. Liu S, Liu B, Luo ZQ, Qiu J, Zhou X, Li G, Zhang B, Deng X, Yang Z, Wang J. The combination of osthole with baicalin protects mice from Staphylococcus aureus pneumonia. World J Microbiol Biotechnol. 2017; 33(1):11. https://doi.org/10.1007/s11274-016-2162-9.

9. Wang J, Zhou X, Li W, Deng X, Deng Y, Niu X. Curcumin protects mice from Staphylococcus aureus pneumonia by interfering with the self-assembly process of a-hemolysin. Sci Rep. 2016:6:28254. https://doi.org/10.1038/ srep28254.

10. Choi KE, Hwang CJ, Gu SM, Park MH, Kim JH, Park JH, Ahn YJ, Kim JY, Song MJ, Song HS, Han SB, Hong JT. Cancer cell growth inhibitory effect of bee venom via increase of death receptor 3 expression and inactivation of NF-kappa B in NSCLC cells. Toxins (Basel). 2014;6(8):221028.

11. Hou C, Guo L, Lin J, You L, Wu W. Production of antibacterial peptide from bee venom via a new strategy for heterologous expression. Mol Biol Rep. 2014:41(12):8081-91.

12. Nascimento de Souza R, Silva FK, Alves de Medeiros M. Bee venom acupuncture reduces Interleukin-6, increases Interleukin-10, and induces Locomotor recovery in a model of spinal cord compression. J Acupunc Meridian Stud. 2017:10(3):204-10.

13. Dotimas EM, Hamid KR, Hider RC, Ragnarsson U. Isolation and structure analysis of bee venom mast cell degranulating peptide. Biochim Biophys Acta. 1987;911(3):285-93

14. Lee $\mathrm{C}$, Bae SS, Joo H, Bae H. Melittin suppresses tumor progression by regulating tumor-associated macrophages in a Lewis lung carcinoma mouse model. Oncotarget. 2017:8(33):54951-65.

15. Lee $\mathrm{G}, \mathrm{Bae} H$. Anti-Inflammatory Applications of Melittin, a Major Component of Bee Venom: Detailed Mechanism of Action and Adverse Effects. Molecules. 2016;11;21(5):616

16. Mourelle D, Brigatte $P$, Bringanti LD, De Souza BM, Arcuri HA, Gomes PC, Baptista-Saidemberg NB, Ruggiero Neto J, Palma MS. Hyperalgesic and edematogenic effects of Secapin-2, a peptide isolated from Africanized honeybee (Apis mellifera) venom. Peptides. 2014;59:42-52.

17. Lee KS, Kim BY, Yoon HJ, Choi YS, Jin BR. Secapin, a bee venom peptide, exhibits anti-fibrinolytic, anti-elastolytic, and anti-microbial activities. Dev Comp Immunol. 2016;63:27-35.

18. Choi JH, Jang AY, Lin S, Lim S, Kim D, Park K, Han SM, Yeo JH, Seo H. Melittin, a honeybee venom-derived antimicrobial peptide, may target methicillin-resistant Staphylococcus aureus. Mol Med Rep. 2015;12(5):6483-90.

19. Clinical and Laboratory Standards Institute. Methods for antimicrobial susceptibility testing of anaerobic Bacteria that grow aerobically; approved standard. 8th ed. Wayne: Clinical and Laboratory Standards Institute; 2009.

20. Huang $G$, Huang $Q$, Xie L, Xiang G, Wang L, Xu H, Ma L, Luo X, Xin J, Zhou $X$, Jin $X$, Zhang $L$. A rapid, low-cost, and microfluidic chip-based system for parallel identification of multiple pathogens related to clinical pneumonia. Sci Rep. 2017;7(1):6441.

21. Sharma V, Sharma S, Dahiya DK, Khan A, Mathur M, Sharma A. Coagulase gene polymorphism, enterotoxigenecity, biofilm production, and antibiotic resistance in Staphylococcus aureus isolated from bovine raw milk in north West India. Ann Clin Microbiol Antimicrob. 2017;16(1):65.

22. Karauzum $H$, Chen $G$, Abaandou L, Mahmoudieh M, Boroun AR, Shulenin S, Devi VS, Stavale E, Warfield KL, Zeitlin L, Roy CJ, Sidhu SS, Aman MJ. Synthetic human monoclonal antibodies toward staphylococcal enterotoxin B (SEB) protective against toxic shock syndrome. J Biol Chem. 2012;287(30): 25203-15.

23. Qiu J, Zhang X, Luo M, Li H, Dong J, Wang J, Leng B, Wang X, Feng H, Ren $W$, Deng $X$. Subinhibitory concentrations of perilla oil affect the expression of secreted virulence factor genes in Staphylococcus aureus. PLoS One. 2011; 6(1):e16160

24. Kim ES, Kang SY, Kim YH, Lee YE, Choi NY, You YO, Kim KJ. Chamaecyparis obtusa essential oil inhibits methicillin-resistant Staphylococcus aureus biofilm formation and expression of virulence factors. J Med Food. 2015; 18(7):810-7. 
25. Zhang H, Zheng Y, Gao H, Xu P, Wang M, Li A, Miao M, Xie X, Deng Y, Zhou $H$, Du H. Identification and characterization of Staphylococcus aureus strains with an incomplete hemolytic phenotype. Front Cell Infect Microbiol. 2016; 6:146 eCollection 2016

26. Da F, Yao L, Su Z, Hou Z, Li Z, Xue X, Meng J, Luo X. Antisense locked nucleic acids targeting agrA inhibit quorum sensing and pathogenesis of community-associated methicillin-resistant Staphylococcus aureus. J Appl Microbiol. 2017;122(1):257-67.

27. Diep BA, Hilliard JJ, Le VT, Tkaczyk C, Le HN, Tran VG, Rao RL, Dip EC, Pereira-Franchi EP, Cha P, Jacobson S, Broome R, Cheng LI, Weiss W, Proka L, Nguyen V, Stover CK, Sellman BR. Targeting Alpha Toxin To Mitigate Its Lethal Toxicity in Ferret and Rabbit Models of Staphylococcus aureus Necrotizing Pneumonia. Antimicrob Agents Chemother. 2017;24;61(4): e02456-16.

28. Kallapur SG, Kramer BW, Moss TJ, Newnham JP, Jobe AH, Ikegami M, Bachurski CJ. Maternal glucocorticoids increase endotoxin-induced lung inflammation in preterm lambs. Am J Physiol Lung Cell Mol Physiol. 2003; 284(4):L633-42.

29. Oda K, Kotani T, Takeuchi T, Ishida T, Shoda T, Isoda K, Yoshida S, Nishimura Y, Makino S. Chemokine profiles of interstitial pneumonia in patients with dermatomyositis: a case control study. Sci Rep. 2017;7(1):1635.

30. Piltonen TT, Chen J, Erikson DW, Spitzer TL, Barragan F, Rabban JT, Huddleston H, Irwin JC, Giudice LC. Mesenchymal stem/progenitors and other endometrial cell types from women with polycystic ovary syndrome (PCOS) display inflammatory and oncogenic potential. J Clin Endocrinol Metab. 2013;98(9):3765-75

31. Bavunoglu I, Genc H, Konukoglu D, Cicekci H, Sozer V, Gelisgen R, Uzun H. Oxidative stress parameters and inflammatory and immune mediators as markers of the severity of sepsis. J Infect Dev Ctries. 2016;10(10):1045-52.

\section{Publisher's Note}

Springer Nature remains neutral with regard to jurisdictional claims in published maps and institutional affiliations.

Ready to submit your research? Choose BMC and benefit from:

- fast, convenient online submission

- thorough peer review by experienced researchers in your field

- rapid publication on acceptance

- support for research data, including large and complex data types

- gold Open Access which fosters wider collaboration and increased citations

- maximum visibility for your research: over $100 \mathrm{M}$ website views per year

At $\mathrm{BMC}$, research is always in progress.

Learn more biomedcentral.com/submissions 